\title{
Sustainable Food and Energy Production. Sugarcane Biorefinery, the Eco-Friendly Appealing 0ption
}

\author{
Oscar Almazán-del Olmo* \\ ICIDCA-Cuban Research Institute of Sugarcane Derivatives (Instituto Cubano de Investigaciones de los Derivados de la Caña de Azúcar), Cuba
}

Submission: June 28, 2021; Published: July 13, 2021

*Corresponding author: Prof. Dr. Oscar Almazán-del Olmo, PhD, ICIDCA-Cuban Research Institute of Sugarcane Derivatives (Instituto Cubano de Investigaciones de los Derivados de la Caña de Azúcar), Via Blanca y Carretera Central 804, San Miguel del Padrón, A.P. 4036, La Habana, Cuba

Keywords: Fossil fuel's sources; Environmental impact; Biorefinery; Healthy human nutrition; Biomasses; Bagasse

\section{Short Communication}

For the first time in history, mankind is evidently unable to get rid of its own residues and also could certainly be victim of its own genius. As the times goes by, (as the song said), this situation is becoming more and more dramatic. If someone thinks it cannot be worst, just read the newspapers. The price of foods is above the once unthinkable figures, conventional fossil fuel's sources are going down to a certain exhaustion.

At the same time, in recent years, biomasses are becoming increasingly appealing alternatives, to give an integrated solution to the hunger, the lack of energy and in an eco-friendly way [1].

At this point, sugarcane represents what someone calls "the marvelous crop", because it not only gives 20 times the energy used to cultivate it but has the capacity to sequester 19 tons of GHG/ha per year, being also able to renew $100 \%$ in 12 months.

British writer, Henry Hobhouse, author of the best-seller "Seed of Change", has described sugar cane as one of the six plant species which have transformed humanity, among the others are tea, cotton and potato. You may not agree with some of the various points raised by him in his book, but we must recognize that sugar cane in much more than a sweet stalk.

This promising sugarcane biomass route received the valuable complement of the innovative concept of BIOREFINERY, not a mere convenient association of technologies, but a wise way to engineer productive installations, to ensure a synergy, that provides the optimum complementation of all the associated plants, to get the most of every individual component, in a coherent complex installation. This concept could be summarized as: "to get the higher overall yield from the raw materials, with the lowest environmental impact, at minimum energy input and giving the most energy output". This would be a true Biorefinery [2].

Recent studies prove that the environmental impacts of the Biorefinery system are lower than the life cycle assessment of fossil fuel system. But it's important to have in mind, that the power of the photosynthesis is not unlimited and the biomass is exhaustible; this will drives to a conclusion: in every circumstances, for every goal, when bagasse is involved, it's unavoidable to make a responsible thermodynamically, environmentally and economically evaluation, to guide the right decision, over how and for what purpose the bagasse will be used [3].

Bagasse is a source of energy and also a valuable raw material for pulp \& paper, particle boards, etc. Another important and valuable component of the sugarcane is the residues of the crop or trash, mainly straws. The amount of residues that can be used depends on the viability of the recovering system used and also, on the quantity that must remain in the fields, to keep the humidity in the soil and to control the growth of weeds. The impact of sugar cane today is still considerable, in a large number of countries and it would even be difficult to imagine many of them, in the tropics, without sugar cane. We should not overlook the fact that sugar, is, with its $4 \mathrm{Kcal} / \mathrm{g}$ and its natural psychological attraction, more than a sweetener and above all, an unrivaled and irreplaceable food, the most pure, simple, healthy and cheapest source of food energy the human race can has, being especially true for that large share of humanity in developing countries [4].

It's clear that today, at the beginning of the 3rd Millennium, almost 3.5 thousand million people are not getting the amount of food they need and deserve; even, may be today, when we 
are reading this, for a child, a woman, an old man, somewhere, a spoonful of sugar, in a glass of water, could means their only opportunity to remain alive. It could sound melodramatic, but unfortunately, it's shamefully true.

The alternative to be selected will always depend on various factors: the production strategy of the industrial complex, the opportunities of the market, the environmental conditions, the scale economy of the specific installations, the most convenient thermodynamically scheme, among others.

So, the decision making about the use of bagasse will be an adequate combination of wisdom, opportunity, local policies and, most of all, the compromise with the survival of the human race... Sugarcane, this exceptional crop, is a certain, reliable and divers source of animal feeds, an important component of the food security, because it's an indisputable fact that meat, milk, fats and their derivatives and co products, are the key elements in a sufficient and healthy human nutrition.

That's the reason why is so important to ensure a solid and sustainable animal production within the tropical zone, almost without exception undeveloped, based on feed sources in full correspondence of the environmental characteristic of the area [5].

When asking "Why Sugarcane in the tropical areas?" the answer is simple: because it gives the higher yields of organic matter per hectare, than any other commercial crop, for fodder energy and protein, under the same fertilizing and irrigation conditions, giving the greatest amount of direct carbohydrates easily assimilable per unit of area, at lower production costs, able to be established with lower investments, long last reproduction without the need of replanting, with high resistance to pests and diseases , better ability to resist successfully to long droughts than other plants [6].

In addition, it's is possible to state that sugarcane offers very wide and economically appealing alternatives of products, that could favor the highly needed industrial development of the tropical countries, meaning more job opportunities, inducing an improve of their global economic balance.

\section{References}

1. Almazán OA (2008) Historia de las levaduras. Editorial Universidad Nacional de Quilmes, Argentina. Serie Nuevos Enfoques en Ciencia y Tecnología, pp. 35-43.

2. Blanco G (1989) Integral evaluation of the alternatives of sugarcane blackstrap molasses. Ph D Thesis. The Central University. Sta. Clara, Cuba.

3. Gálvez LO, Álvarez A, Almazán OA, Otero MA, Sabadí R, et al. (2008) Editorial ICIDCA, Compendio de los Derivados de la Caña de Azúcar.

4. Martinez JA, Almazán OA, Saura G, Otero MA (2004) Production of fodder yeast from vinasses in Cuba: an environmental approach. Zuckerindustrie 129(2): 92-95.

5. Almazán OA, Klibansky MM, Otero MA (1981) Microbial fat synthesis in Rhodotorula glutinis from blackstrap molasses in continuous culture. Biotechnological Letters 3(11): 663-666.

6. Otero MA, Almazán OA (2012) Las levaduras como base de una industria. Diferentes aplicaciones. Editorial Académicas Españolas.

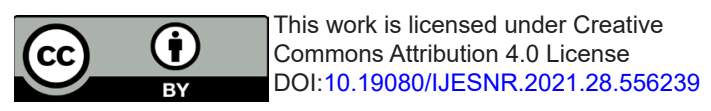

\section{Your next submission with Juniper Publishers will reach you the below assets}

- Quality Editorial service

- Swift Peer Review

- Reprints availability

- E-prints Service

- Manuscript Podcast for convenient understanding

- Global attainment for your research

- Manuscript accessibility in different formats

( Pdf, E-pub, Full Text, Audio)

- Unceasing customer service

Track the below URL for one-step submission https://juniperpublishers.com/online-submission.php 